\section{Ornate cabinet}

By Rachel Bairsto, Head of Museum Services, British Dental Association Museum

Workplace furniture design in the late nineteenth century often followed one of two paths: functional or ornate. The aesthetic movement in Britain between 1860-1900 aimed to escape the industrial ugliness and practical function, and focus on producing art and design that was beautiful. This cabinet is made in the style of architect and furniture designer of this period, T. E. Collcutt. Although it seems eminently ideal for displaying blue and white porcelain, it could also plausibly find its way from a drawing room to a dentist's surgery.

The ornate ebonised balustrade rail over the front flap compartment is faced with ceramic tiles. There is a small, square lockable cupboard, by itself, in the centre. The drawers and cupboards are decorated with blue and cream tiles of children at play. Some of the scenes are easily recognisable, such as boys playing cricket, but in others, it is not clear quite what is happening.

The designer of the tiles is uncertain. It may have been Kate Greenaway, one of the most popular book illustrators of the late nineteenth century, or a possible candidate is Walter Crane, another leading book illustrator of the period. Through his

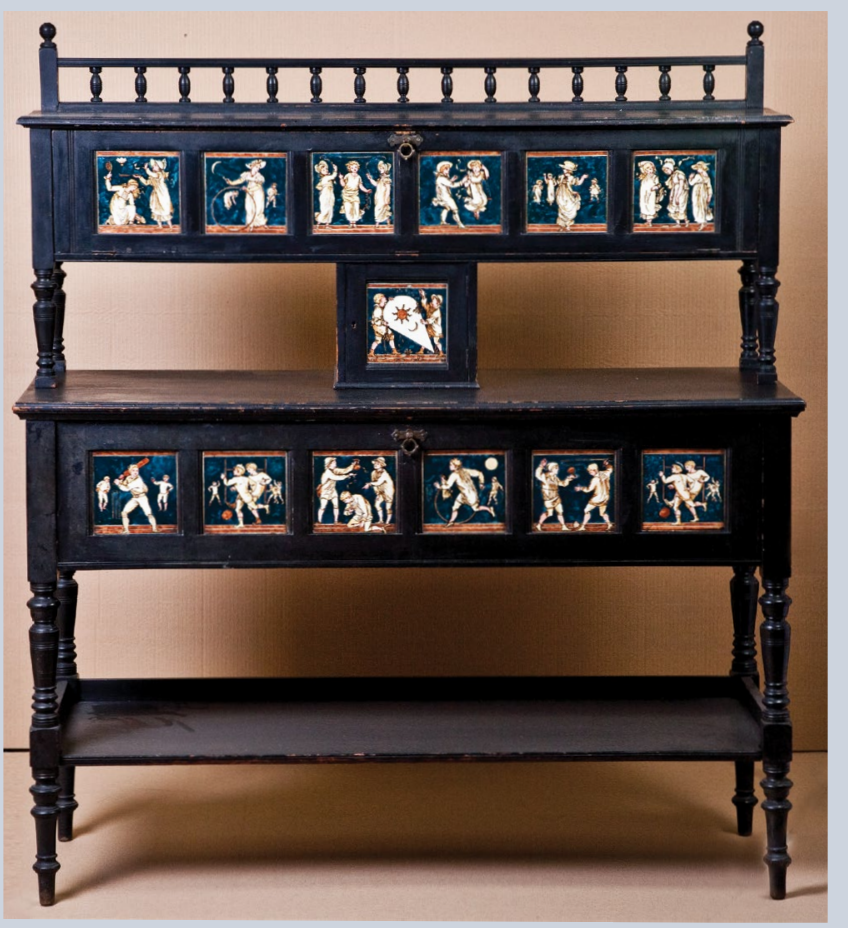

friendship with William Morris, Walter Crane produced designs for the Arts and Crafts Society as well as political cartoons promoting socialism. A third possibility is given in the BDA Library and Museum Committee Minutes of 4 October 1961 recording the donation, which say the tiles are believed to be '...the work of famous tile maker Moore'. Unfortunately, the museum staff cannot identify which 'Moore' this may be; if any reader can help, we would like to hear from you.

The cabinet was donated to the BDA by Mr W. Breeze and it had formerly been the property of Sir Norman Bennett, President of the Association in 1930, and before that belonged to James Parkinson, a leading member of the Dental Reform Committee, which campaigned for the 1878 Dentists Act, and the first treasurer of the BDA. This history of ownership adds to the importance of the cabinet; it is not just a fascinating artefact, but its association with such men brings a social context to it. The personal stories and connections behind museum objects can often be as important as their heritage value.

\section{BDA Presidential Meeting}

The British Dental Association's (BDA's) presidential installation ceremony will take place virtually on Tuesday 7 September 2021 at 20:00-20:30.

Outgoing President Russ Ladwa will give his valedictory address and incoming President Liz Kay will give her presidential speech.

To register to attend the event, visit https://www.bda. org/events/online-event/bda-presidential-meeting-7september-2021. The event is open to all. 